\title{
THE RELATIONSHIP OF PERSISTENT DRUG USE WITH DIRECT MEDICAL COST IN PATIENTS WITH SYSTOLIC HEART FAILURE
}

\author{
Ratih Puspita Febrinasari'), Bambang Irawan Martohusodo's), \\ Erna Kristin3, Iwan Dwiprahasto3 \\ 1)Department of Pharmacology and Therapy, Faculty of Medicine Universitas Sebelas Maret \\ ${ }^{2)}$ Department of Cardiology, Faculty of Medicine, Public Health, and Nursing, \\ Universitas Gadjah Mada \\ 3)Department of Pharmacology and Therapy, Faculty of Medicine, \\ Public Health and Nursing Universitas Gadjah Mada
}

\begin{abstract}
Background: Heart failure is the final stage of heart disease and causes high mortality and morbidity. Systolic heart failure (SHF) characterized by decreased ejection fraction (EF) and co-morbidities increases the incidence of re-hospitalization and also direct medical costs borne by the patient. Heart failure requires obedience in treatment or persistent treatment. This study aimed to determine the medical cost between persistent and non-persistent groups in SHF patients.

Subjects and Method: This was a retrospective cohort study. The SHF patients were selected for this study by consecutive sampling. The direct medical costs between groups were compared between persistent and not persistent in treatment. The data were collected from the medical record and analyzed using chi-square.

Results: From the 284 SHF patients, $61.2 \%$ were not persistent with the treatment. The average total cost did not differ between persistent groups (IDR 43,816,676) and non-persistent (IDR 52,657,002). The cost of persistent outpatient groups (IDR $4,718,873$ ) was lower than the non-persistent (IDR 8,360,082), and it was statistically significant $(\mathrm{p}<0.05)$.
\end{abstract}

Conclusion: Persistent outpatient group costs are lower than non-persistent ones.

Keywords: systolic heart failure, persistent, costs

\section{Correspondence:}

Ratih Puspita Febrinasari. Department of Pharmacology and Therapy, Faculty of Medicine Universitas Sebelas Maret, Surakarta, Central Java. Email: ratihpuspita@staff.uns.ac.id. Mobile: +6281229722727 .

The $6^{\text {th }}$ International Conference on Public Health Best Western Premier Hotel, Solo, Indonesia, October 23-24, 2019 | 256 